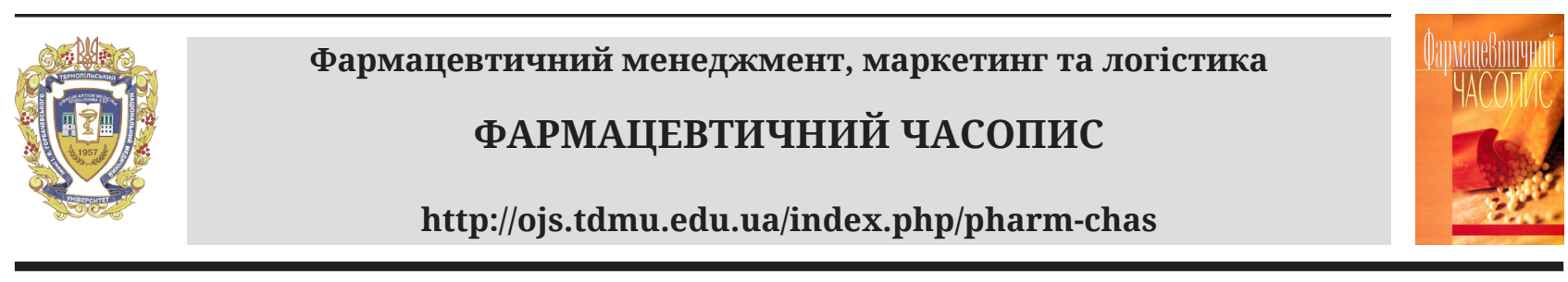

УДК 615.1:615.322:338.33

DOI https://doi.org/10.11603/2312-0967.2021.2.12126

\title{
АНАЛІЗ ВІТЧИЗНЯНОГО РИНКУ ЛІКАРСЬКИХ ЗАСОБІВ, ЯКІ ЗАСТОСОВУЮТЬ ПРИ ЗАХВОРЮВАННЯХ ПОРОЖНИНИ НОСА
}

\author{
Н. Є. Стадницька, Ж. Д. Паращин, І. П. Лобур, І. В. Фітьо \\ Національний університет «Львівська політехніка» \\ nataliia.y.stadnytska@lpnu.ua
}

ІНФОРМАЦІЯ

Надійшла до редакції / Received: 17.02.2021

Після доопрацювання / Revised: 23.04.2021

Прийнято до друку / Accepted: 27.04.2021

\section{Ключові слова}

фармацевтичний ринок;

захворювання порожнини носа; спреї;

назальні краплі.
АНОТАЦІЯ

Мета роботи. Провести аналіз сучасного асортименту лікарських препаратів фармацевтичного ринку України для лікування захворювань порожнини носа (код ATC R01) з урахуванням складу, діючих речовин, фрорм випуску, виробників.

Матеріали і методи. Робота виконана з використанням офріційних джерел інфрормації, дані з яких були опрацьовані, систематизовані з використанням статистичного, логічного і графрічного методів.

Результати й обговорення. В результаті проведеного аналізу встановлено, що на фрармацевтичному ринку України найбільше лікарських засобів для лікування захворювань порожнини носа зареєстровано у фрормі спрею (67,16 \%); однокомпонентні лікарські засоби становлять переважаючу частку асортименту $(76,12 \%)$. Ксилометазолін як діючу речовину застосовують найчастіше (35,07 \%). На українському ринку домінують імпортні лікарські препарати (61,94%). Лідером серед українських фрармацевтичних підприємств-виробників є ПАТ «Фармак» (41,18\%).

Висновки. Аналіз ринку лікарських засобів, які застосовують при захворюваннях порожнини носа, показав, що вони належать до різних фармакологічних груп. На ринку представлені якмоно-, такібагатокомпонентні препарати переважно у формі спреїв та крапель. Асортимент українських препаратів забезпечують 8 фрармацевтичних підприємств-виробників, лідером серед яких є ПАТ «Фармак» $(41,18 \%)$.
Вступ. Інфекційні захворювання верхніх дихальних шляхів $€$ найпоширенішими, з якими людина стикається впродовж життя. Згідно 3 класифікацією Всесвітньої організації охорони здоров'я такі захворювання верхніх дихальних шляхів, як нежить (гострий назофрарингіт), назофрарингіт і фрарингіт, гострий та хронічний синусит, хронічний, вазомоторний та алергічний риніт належать до групи «Гострі респіраторні інфекції верхніх дихальних шляхів (J00-J06)» [1]. Клінічна картина цих захворювань проявляється переважно симптомами інтоксикації та катаральних змін слизової оболонки верхніх дихальних шляхів (порожнина носа, глотки), які часом поєднуються із запаленням нижніх (гортань, трахея, бронхи) дихальних шляхів і легень. Провідними чинниками гострих станів $€$ вірусна фрлора, реактивний

ISSN 2312-0967. Фармацевтичний часопис. 2021. № 2 
набряк, порушення реології секрету та локальний імунодефріцит, внаслідок чого можливе приєднання бактеріальної інфрекції. Обґрунтоване лікування вимагає призначення препаратів протинабрякової, протизапальної, секретолітичної, імуностимулювальної та протиіноекційної дії [2]. Основною вимогою до таких засобів є поєднання компонентів, які б забезпечували оптимальний терапевтичний ефект. Комбінації діючих речовин із різних фрармакологічних груп не тільки підсилюють їх фрармакотерапевтичну дію, а й дають можливість застосування при багатьох патологічних процесах та додатково при ЛОР-хірургічних втручаннях. Алергічний риніт і гострий риносинусит мають спільні механізми і схожу симптоматику. Терапія потребує впливу на основні чинники, що спричиняють захворювання, насамперед, алергени. 3 цією метою застосовують іригаційну терапію на слизову оболонку або специорічну імунотерапію причинними алергенами. Набряк слизової оболонки потребує протинабрякового, алергічне запалення - протизапального, порушення реології секрету - мукоактивного впливу [3]. Захворювання може бути сезонним (під час цвітіння деяких рослин) або тривати цілий рік (якщо має місце алергія на конкретні подразники).

Оптимальний фрармакотерапевтичний ефект досягають при використанні лікарських засобів групи R 01.

Відповідно до АТС-класифрікації (Anatomical Therapeutic Chemical) лікарські засоби R01 [4], які застосовують при захворюваннях порожнини носа, поділяють на дві групи:

- R01A протинабрякові та інші препарати для місцевого застосування в разі захворювань порожнини носа;

- R01B системно діючі протинабрякові засоби, що застосовуються у разі патології порожнини Hoca.

Відповідно групу R01A поділяють на кілька підгруп залежно від діючих речовин та їхньої фрармакологічної дії:

- R 01A A - симпатоміметики, прості препарати;

- R 01A B - симпатоміметики в комбінації з іншими засобами (за винятком кортикостероїдів);

- R 01A C - протиалергійні засоби, за винятком кортикостероїдів;

- R 01A D - кортикостероїди;

- R 01A X - інші засоби для лікування захворювання носа.

Питання дослідження лікарських засобів, які використовують при захворюваннях порожнини носа, розглядають у ряді публікацій вітчизняних науковців [5-8], але частіше аналізують препарати за їхньою фрармакологічною дією і застосуванням при даній патології та в комплексній терапії запальних процесів верхніх дихальних шляхів. Тому, зважаючи на частоту і поширеність патології порожнини носа, доцільне дослідження сучасного стану асортименту лікар- ських засобів даної групи на фрармацевтичному ринку України.

Мета роботи: провести аналіз сучасного асортименту лікарських препаратів фрармацевтичного ринку України для лікування захворювань порожнини носа (код ATC R01).

Матеріали і методи. Дослідження асортименту лікарських засобів здійснено згідно з Державним реєстром лікарських засобів України [9] та класифрікаційною системою ATC (Anatomical Therapeutic Chemical classification system) за параметрами: склад, діючі речовини, лікарська форма, виробник. Для аналізу використано статистичний, логічний i графрічний методи.

Результати й обговорення. Аналіз даних Держреєстру лікарських засобів України станом на лютий 2021 року показав, що група препаратів R01, які застосовують при захворюваннях порожнини носа, налічує 196 назв [9]. Для проведення статистичних розрахунків препарати з однією оригінальною назвою та лікарською фрормою, але 3 різними концентраціями діючих речовин були розглянуті як одна одиниця. Відповідно для розрахунків загальна кількість назв препаратів зменшилася до 134.

За результатами дослідження фрармацевтичного ринку найчастіше лікарські засоби, які застосовуються при захворюваннях порожнини носа (група R01), представлені у вигляді спреїв - 67,16 \% та крапель - 26,86 \%. Менша частка належить препаратам у фрормі порошків для інтраназального розчину 2,24 \%, гелю - 1,49 \%, розчину, бальзаму для інгаляцій в олівці і таблеток, відповідно, по 0,75 \%. Препарати груп R01AC i R01AD представлені винятково у фрормі спреїв. Проаналізовані нами лікарські форми окремо по кожній підгрупі подано на рисунку 1.

При дослідженні лікарських засобів для лікування порожнини носа за АТС-класифрікацією встановлено, що підгрупа R01A A представлена 72 найменуваннями. Діючими речовинами простих препаратів симпатоміметиків є ксилометазолін (48,61 \%), оксиметазолін (40,28\%), нафразолін (5,56 \%), френілефрин $(4,16 \%)$, трамазолін (1,39\%). Їхня протинабрякова дія проявляється через 3-10 хв та триває від 4 до 12 год. Рекомендовано застосовувати препарати даної групи не довше трьох діб, оскільки можливе виникнення побічних есректів [10].

Підгрупа R01AB представлена 23 найменуваннями. Для підсилення фрармакотерапевтичного ефректу симпатоміметики застосовують у комбінації з іншими засобами (за винятком кортикостероїдів). Найчастіше спостерігається поєднання ксилометазоліну 3 дексапантенолом, мірамістином, іпратропію бромідом - 52,17 \%, френілефрину 3 диметинденом $34,78 \%$, нафразоліну, оксиметазоліну, туаміногептану - по 4,35\% .

Підгрупа R01AC «Протиалергійні засоби, за виключенням кортикостероїдів» представлена лише

ISSN 2312-0967. Pharmaceutical review. 2021. № 2 
Фармацевтичний менеджмент, маркетинг та логістика

Pharmaceutical management, marketing and logistics

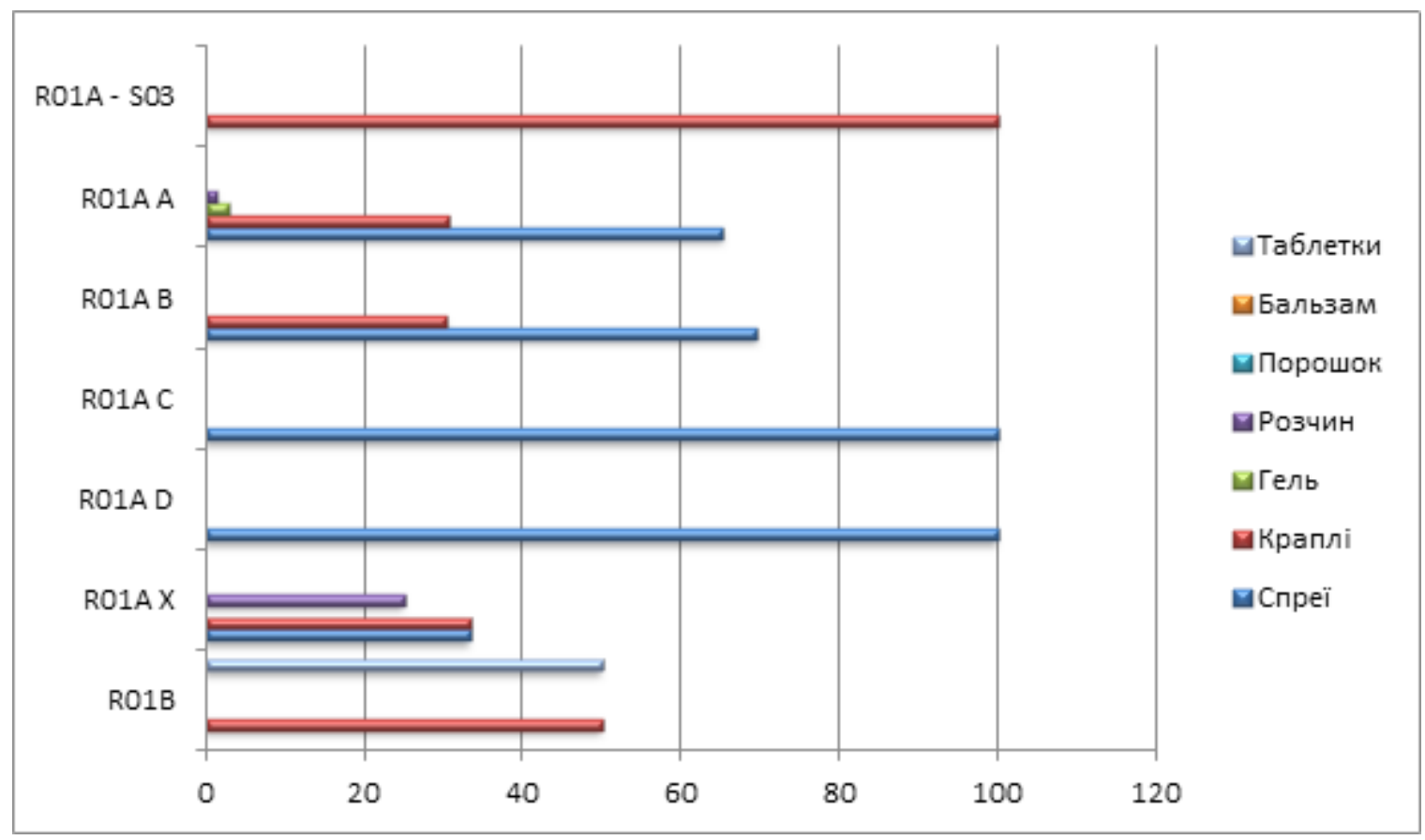

Рис. 1. Частка лікарських фрорм у підгрупах R01, представлених на фрармацевтичному ринку України.

3 найменуваннями: 3 діючими речовинами азеластин - 66,7 \% і кромоглікат натрію 33,3 \%.

Підгрупа R01AD «Кортикостероїди» представлена 20 препаратами, які систематизовані за діючими речовинами, проявляють протизапальну і протиалергічну дію. Найчастіше використовують мометазон (65 \%) і фрлютиказон (20 \%) як у вигляді монопрепаратів, так і в комбінації з представниками інших фрармакологічних груп. Рідше застосовують дексаметазон (5 \%), беклометазон (5 \%), будесонід (5 \%).

Підгрупа R01AX «Інші засоби для лікування захворювання носа» представлена 12 найменуваннями, діючими речовинами яких є сполуки природного і синтетичного походження, зокрема протаргол (25 \%), натрію хлорид (33,34 \%), есрірні олії (25\%), фрраміцетин (8,33\%), цикламен (8,33\%). Терапевтичний ефрект препаратів даної групи не дуже виражений і проявляється внаслідок комплексного поєднання значної кількості інгредієнтів.

Згідно з Державним реєстром препарати Окомістин та Оортамірин віднесені до групи R01A, а за даними Компендіум - до групи S03 (засоби, що діють на органи чуття; препарати, які використовують в офртальмології та отології), тому в інструкціях препаратів подано подвійну АТС-класисрікацію $[9,10]$.

До групи препаратів R01B «Системно діючі протинабрякові засоби, що застосовуються у разі патології порожнини носа» належать Мілі Носік - краплі оральні (діючі речовини френілесрин, хлорфенірамін) та Ефіна - таблетки (діючі речовини псевдоефедрин, трипролідин).
При проведенні аналізу асортименту лікарських засобів для лікування порожнини носа встановлено, що найчисельнішою підгрупою є R01AA (53,73 \%). Майже однакова кількість препаратів належить до підгрупи R01AB (17,16 \%) та підгрупи R01AD $(14,93 \%)$. Менше препаратів налічують підгрупи R01AC (2,24 \%), R01AX (8,96 \%), R01B (1,49\%), R01A-S03 (1,49 \%) (рис. 2). Діючі речовини, які входять до складу цих препаратів, належать до різних фрармакологічних груп. Найпоширенішими $€$ ксилометазолін - 47 препаратів (35,07\%), оксиметазолін - 30 (22,39 \%), мометазон - 13 (8,96 \%), френілефрин - 12 (8,95 \%), диметинден - 8 (5,97\%), дексапантенол -7 (5,22 \%). Менше представлені препарати з нафразоліном (3,73 \%), азеластином (2,99\%), фрлютиказоном (2,99\%), натрію хлоридом (2,99\%), іпраторопію бромідом, мірамістином, олією евкаліпта, протарголом - по 2,24 \%, олією м'яти, ментолом - по 1,49 \%. Номенклатура даної групи препаратів охоплює всі вікові категорії населення, забезпечує оптимальні дози діючих речовин.

Аналіз фрармацевтичного ринку показав, що більшість асортименту досліджених препаратів для лікування порожнини носа складають однокомпонентні - 102 найменування (76,12 \%), двокомпонентні препарати нараховують 27 найменувань $(20,15 \%)$, а багатокомпонентні - лише 5 найменувань (3,73 \%) (рис. 3). У двокомпонентних препаратах застосовують такі поєднання діючих речовин, як симпатоміметики 3 антигістамінними $(34,38 \%)$, симпатоміметики 3 провітаміном $\mathrm{B}_{5}$

ISSN 2312-0967. Фармацевтичний часопис. 2021. № 2 


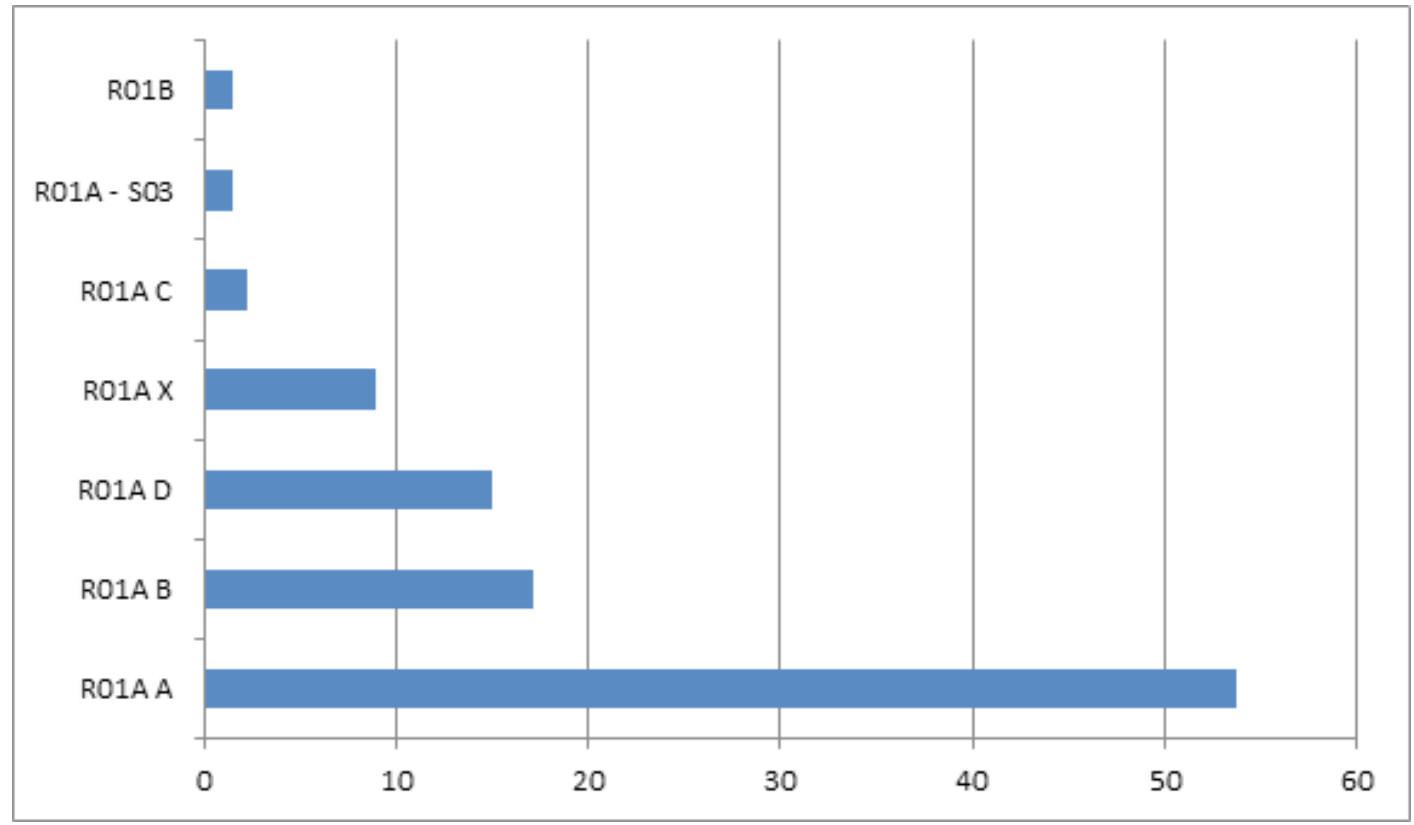

Рис. 2. Частка препаратів за підгрупами групи R 01.

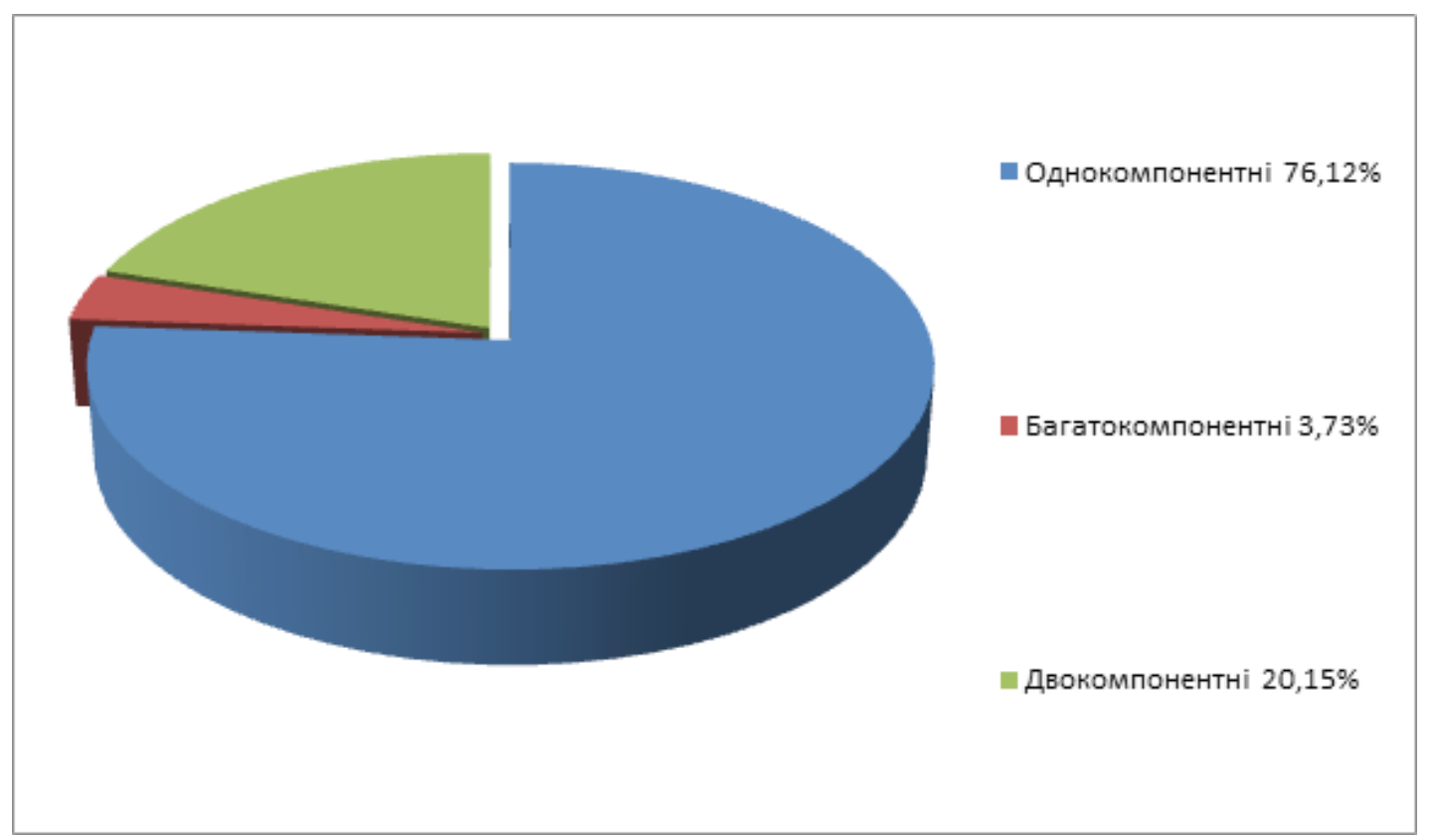

Рис. 3. Розподіл лікарських препаратів за кількісним складом.

(21,88\%), кортикостероїди 3 антигістамінними $(9,38 \%)$, симпатоміметики 3 м-холінолітиками (9,38 \%), симпатоміметики з антисептиком, муколітиком, ефрірною олією - по 3,13 \%. До складу багатокомпонентних препаратів також входять антибіотики, ментол, камфрора, тимол [11].

За результатами аналізу встановлено, що на фрармацевтичному ринку України більшість препаратів (61,94 \%) із кодом ATC R01 імпортовані 3 інших країн світу. Частка лікарських засобів, виго- товлених на вітчизняних фрармацевтичних підприємствах, становить 38,06 \%. Лідером серед українських фрірм-виробників (рис. 4) є ПАТ «Фармак» м. Київ 41,18 \%, другу позицію займає ТОВ «Фармацевтична компанія «Здоров'я» м. Харків 25,49 \%, третю та четверту займають українськоіспанське СП «Сперко» М. Вінниця 9,81 \% та ПрАТ «Фармацевтична фрірма «Дарниця» м. Київ 7,84 \%. Дещо менше препаратів випускають ТОВ «Мікрофрарм» м. Харків 5,88 \%, ПАТ «Хімзавод Червона

ISSN 2312-0967. Pharmaceutical review. 2021. № 2 
Фармацевтичний менеджмент, маркетинг та логістика

Pharmaceutical management, marketing and logistics

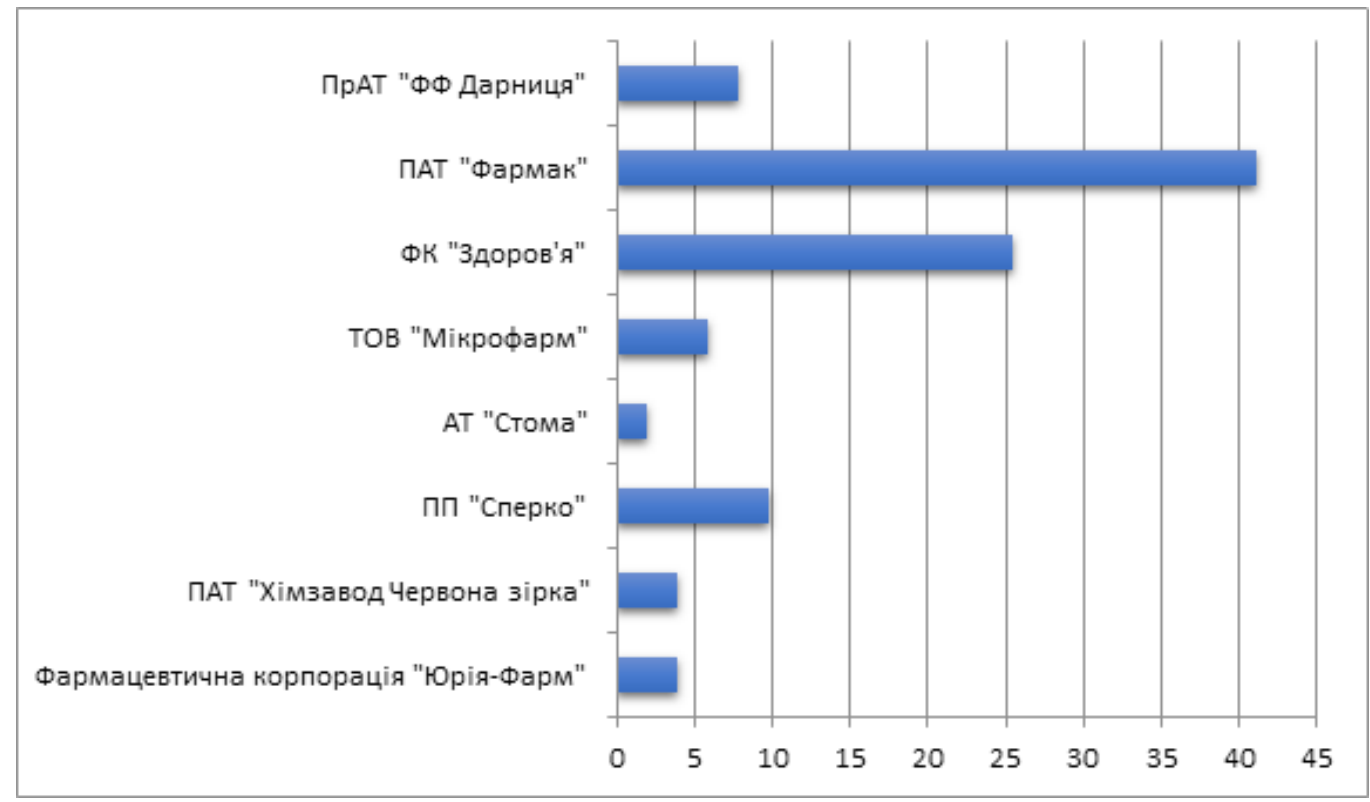

Рис. 4. Розподіл виробників лікарських засобів групи R01 в Україні.

зірка» м. Харків та Фармацевтична корпорація «Юрія-срарм» м. Черкаси - по 3,92 \% і АТ «Стома» м. Харків - 1,96\% .

Найбільшим імпортером препаратів даної групи $€$ Німеччина (19,27 \%), меншу частку в імпорті ліків до
України мають Італія, Іспанія, (8,43%), Франція, Швейцарія, Чехія, Індія (7,23 \%), Туреччина, Словенія, Румунія (4,82 \%) Польща, Хорватія (3,61 \%), Португалія, Бельгія, Білорусь, Молдова (2,41 \%) та інші $(3,66 \%)$ (рис. 5).

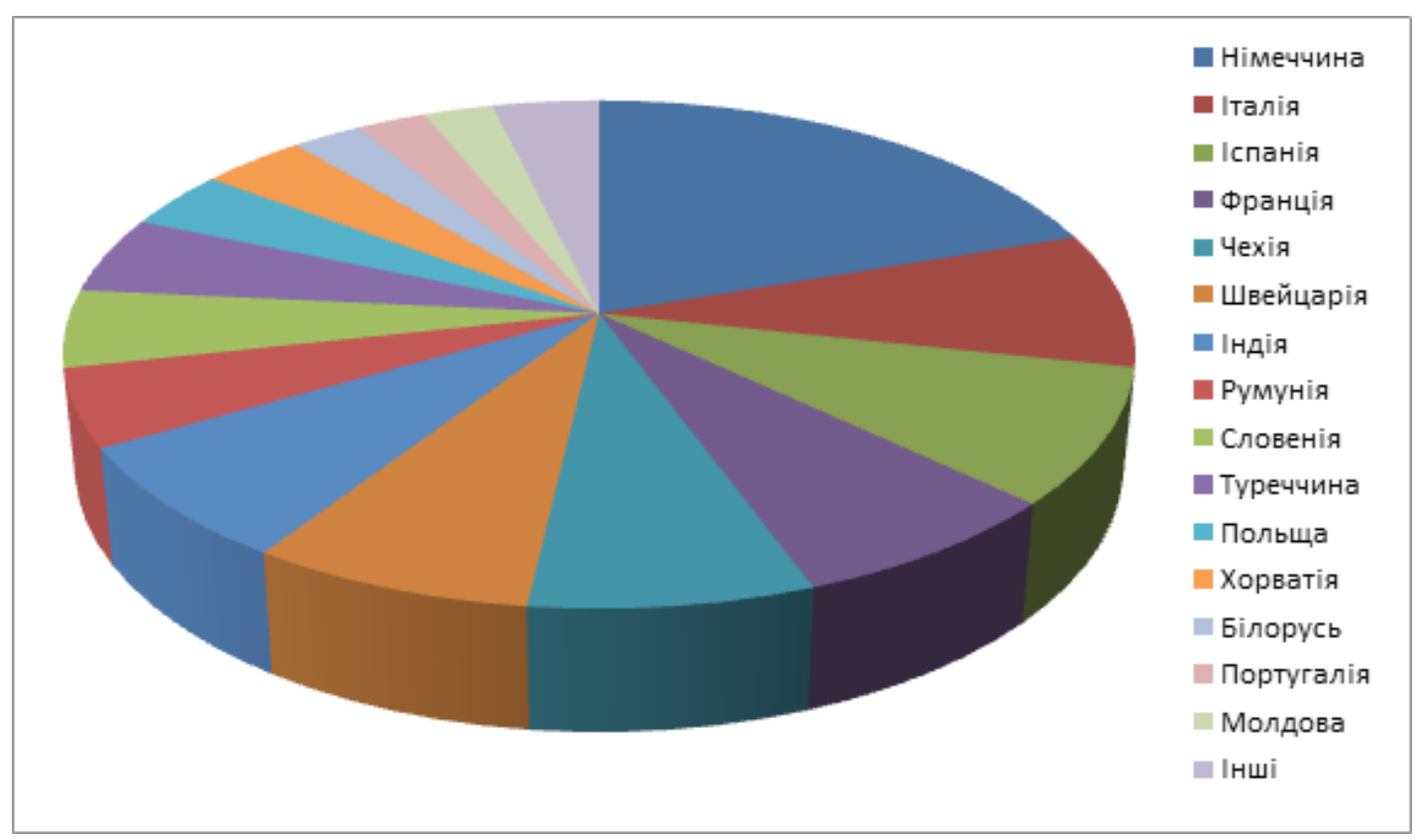

Рис. 5. Країни-виробники лікарських засобів, представлені на фрармацевтичному ринку України.

Висновки. В результаті проведеного аналізу асортименту лікарських засобів, які застосовують при захворюваннях порожнини носа, групи
R01 за Державним реєстром лікарських засобів України та класифрікаційною системою АТС встановлено:

ISSN 2312-0967. Фармацевтичний часопис. 2021. № 2 
Фармацевтичний менеджмент, маркетинг та логістика

Pharmaceutical management, marketing and logistics

- найбільше лікарських засобів зареєстровано у фрормі спрею (67,16 \%); протиалергічні препарати і кортикостероїди представлені винятково у вигляді спреїв, а симпатоміметики та інші засоби для лікування - у різних формах;

- препарати групи R01 належать до різних фрармакологічних груп, зокрема симпатоміметиків, кортикостероїдів антигістамінних, антибактеріальних; найчастіше до складу препаратів, як діюча речовина, входить симпатоміметик ксилометазолін (35,07 \%);

- більшість асортименту складають однокомпонентні препарати (76,12\%), що свідчить про доцільність розширення номенклатури комбінованих лікарських засобів для забезпечення оптимальної фрармакотерапії;

- на фрармацевтичному ринку домінують закордонні лікарські засоби (61,94 \%), найбільшим імпортером є Німеччина ( 19,27 \%);

- асортимент українських препаратів забезпечують 8 фрармацевтичних підприємств-виробників, лідером серед яких $€$ ПАТ «Фармак» $(41,18 \%)$.

Конфрлікт інтересів: відсутній.

Conflicts of interest: authors have no conflict of interest to declare.

\title{
ANALYSIS OF THE INTERNAL MARKET OF MEDICINES USED IN DISEASES OF THE NASAL CAVITY
}

\author{
N. Ye. Stadnytska, Zh. D. Parashchyn, I. P. Lobur, I.V. Fito \\ Lviv Polytechnic National University \\ nataliia.y.stadnytska@lpnu.ua
}

The aim of the work. To analyze the current range of drugs of the pharmaceutical market of Ukraine for the treatment of diseases of the nasal cavity (ATS code R01), taking into account the composition, active substances, dosage forms, manufacturers.

Materials and Methods. The work was performed using official sources of information, data from which were processed, systematized using statistical, logical and graphical methods.

Results and Discussion. As a result of the analysis, it was found that in the pharmaceutical market of Ukraine most drugs for the treatment of diseases of the nasal cavity are registered in the form of sprays (67.16 \%); single-component drugs make up the predominant share of the range (76.12\%). Xylometazoline as the active substance is used most often (35.07\%). Imported drugs dominate the Ukrainian market (62 \%). The leader among Ukrainian pharmaceutical companies is PJSC "Farmak" (41.18\%).

Conclusions. Analysis of the market of drugs used in diseases of the nasal cavity, showed that they belong to different pharmacological groups. Both mono- and multicomponent preparations are presented on the market mainly in the form of sprays and drops. The range of Ukrainian drugs is provided by 8 pharmaceutical manufacturers, the leader among which is PJSC "Farmak" (41.18\%).

Key words: pharmaceutical market; diseases of the nasal cavity; sprays; nasal drops.

\section{АНАЛИЗ ОТЕЧЕСТВЕННОГО РЫНКА ЛЕКАРСТВЕННЫХ ПРЕПАРАТОВ, КОТОРЫЕ ИСПОЛЬЗУЮТСЯ ПРИ ЗАБОЛЕВАНИЯХ ПОЛОСТИ НОСА}

\author{
Н. Е. Стадницкая, Ж. Д. Паращин, И. П. Лобур, И. В. Фитьо \\ Львовский политехнический национальный университет \\ nataliia.y.stadnytska@lpnu.ua
}

Цель работы. Провести анализ современного ассортимента лекарственных препаратов фрармацевтического рынка Украины для лечения заболеваний полости носа (код ATC Ro1) с учетом состава, действующих веществ, форм выпуска, производителей.

Материалы и методы. Работа выполнена с использованием официальных источников информации, данные с которых были обработаны, систематизированы с использованием статистического, логического и графического методов.

Результаты и обсуждение. В результате проведенного анализа установлено, что на фрармацевтическом рынке Украины больше лекарственных средств для лечения заболеваний полости носа зарегистрировано в форме спрея (67,16 \%); однокомпонентные лекарственные средства составляют преобладающую долю ассортимента (76,12 \%).

ISSN 2312-0967. Pharmaceutical review. 2021. № 2 
Фармацевтичний менеджмент, маркетинг та логістика

Pharmaceutical management, marketing and logistics

Ксилометазолин как действующее вещество применяется чаще всего (35,07 \%). На украинском рынке доминируют импортные лекарственные препараты (62 \%). Лидером среди украинских фрармацевтических предприятийпроизводителей является ОАО «Фармак» (41,18 \%).

Выводы. Анализ рынка лекарственных средств, применяемых при заболеваниях полости носа, показал, что они относятся к разным фрармакологическим группам. На рынке представлены как моно-, так и многокомпонентные препараты преимущественно в фрорме спреев и капель. Ассортимент украинских препаратов обеспечивают 8 фрармацевтических предприятий-производителей, лидером среди которых является ОАО «Фармак» (41,18 \%).

Ключевые слова: фрармацевтический рынок; заболевания полости носа; спреи; назальные капли.

\section{Список бібліографічних посилань}

1. Європейська база даних статистичної інфрормації «Здоров'я для всіх». URL: from: http://medstat.gov. ua/ukr/normdoc.html.

2. Попович В.І. Гострий вірусний риносинусит: сучасн погляди на етіопатогенез, діагностику та лікування. Семейная медицина. 2015. № 2. C. 158-160. URL: http://nbuv.gov.ua/UJRN/simmed_2015_2_34.

3. Попович В. І. Алергічний риніт: сучасні підходи до діагностики та лікування. Український медичний часопис. 2018. № 3 (125), T. 1 V-VI. C. 64-65.

4. Спеціалізоване медичне інтернет-видання для лікарів, провізорів, фрармацевтів, студентів медичних і фрармацевтичних вузів «Компендіум». URL: https://compendium.com.ua.

5. Експериментальне дослідження фрармакологічної активності назального спрею мометазону 3 оксиметазоліном / Чайка Л. О. та ін. Фармакологія та лікарська токсикологія. 2018. № 4-5. С. 42-52. URL: http://nbuv.gov.ua/UJRN/flt_2018_4-5_8

6. Кухтенко О. С., Гладух Є. В., Сімонян Л. С. Аналіз вітчизняного ринку лікарських засобів для лікування запальних захворювань дихальних шляхів.
Управління, економіка та забезпечення якості в фрармації. 2017. № 4 (52). С. 42-49.

7. Захворюваність на гострі інфекції верхніх дихальних шляхів множинної або невизначеної локалізації серед дитячого населення України / Трихліб В. І. та ін. Актуальная инфектология. 2016. № 3. С. 83-92. URL: http://nbuv.gov.ua/UJRN/akinf_2016_3_17

8. Біль Б. Н., Кушнір А. С., Назаренко А. М. Препарати Полідекса з оренілесрином і Ізофрра в місцевому лікуванні ринологічних захворювань. Семейная медицина. 2014. № 1. C. 85-88. URL: http://nbuv.gov. ua/UJRN/simmed_2014_1_19

9. Державний реєстр лікарських засобів України. URL: http://www.drlz.com.ua

10. Ліки Контроль. URL: http://likicontrol.com.ua

11. Дєєва Ю. В. Безшапочний С. Б. Препарати місцевої антибактеріальної терапії, як складова лікування запальних захворювань порожнини носа та приносових пазух. Вісник проблем біології і медицини. 2019. Вип. 1 (1). T 1 (148). С. 106-111. URL: http:// nbuv.gov.ua/UJRN/Npbm_2019_1 \% $281 \%$ 29_24 DOI 10.29254/2077-4214-2019-1-1-148-106-111

\section{References}

1. European Health for All Statistical Database. Available from: http://medstat.gov.ua/ukr/normdoc.html.

2. Popovych VI. [Acute viral rhinosinusitis: modern views on etiopathogenesis, diagnosis and treatment]. Semeynaya meditsina. 2015;2: 158-60. Ukrainian.

3. Popovych VI. [Allergic rhinitis: modern approaches to diagnosis and treatment]. Ukrainskyi medychnyi chasopys. 2018;3:(125),V-VI: 64-5. Ukrainian.

4. Compendium Directory [Internet]. Available from: http:// compendium.com.ua. URL: https://compendium.com. ua.

5. Chaika LO, Deieva TV, Nikitina NS, Tymchenko OV, Libina VV, Andrianova TV, Bezuhla OP. [Experimental study of the pharmacological activity of mometasone nasal spray with oxymetazoline]. Farmakolohiia ta likarska toksykolohiia. 2018;4-5: 42-52. Available from: http://nbuv.gov.ua/UJRN/flt_2018_4-5_8.

6. Kukhtenko OS, Hladukh YeV, Simonian LS. [Analysis of the domestic market of drugs for the treatment of inflammatory diseases of the respiratory tract]. Upravlinnia, ekonomika ta zabezpechennia yakosti v farmatsii. 2017;4(52): 42-9.

7. Trykhlib VI., Zadorozhna VI, Tkachuk SI, Palatna LO, Operchuk NI.[ Incidence of acute upper respiratory tract infections of multiple or indeterminate localization among the pediatric population of Ukraine]. Aktualnaya infektologiya. 2016;3: 83-92. Available from: http:// nbuv.gov.ua/UJRN/akinf_2016_3_17. Ukrainian.

8. Bil BN, Kushnir AS, Nazarenko AM [Polydex drugs with phenylephrine and Isofra in the local treatment of rhinological diseases]. Semeynaya meditsina. 2014;1: 85-8. Available from: http://nbuv.gov.ua/UJRN/ simmed_2014_1_19. Ukrainian.

9. State Register of Medicines of Ukraine. [Державний реєстр лікарських засобів України] Available from: http://www.drlz.kiev.ua/ Ukrainian.

10. Medicine Control. Available from: http://likicontrol.com.ua

11. Dieieva YuV, Bezshapochnyi SB. [Drugs of local antibacterial therapy as a component of treatment of inflammatory diseases of the nasal cavity and paranasal sinuses]. Visnyk problem biolohii i medytsyny. 2019;1(48): 106-11. Available from:: http://nbuv.gov.ua/UJRN/Vpbm_2019_1 \% $281 \% 2924$ DOI 10.29254/2077-4214-2019-1-1148-106-111. Ukrainian.

ISSN 2312-0967. Фармацевтичний часопис. 2021. № 2 
Фармацевтичний менеджмент, маркетинг та логістика Pharmaceutical management, marketing and logistics

\section{Відомості про авторів}

Стадницька Н. Є. - канд. хім. наук, доцент кафедри технології біологічно активних сполук, фармації та біотехнології, Національний університет «Львівська політехніка», Львів, Україна. E-mail: nataliia.y.stadnytska@Ipnu.ua, ORCID 0000-0001-6261-0275.

Паращин Ж. Д. - канд. хім. наук, доцент кафредри технології біологічно активних сполук, срармації та біотехнології, Національний університет «Львівська політехніка», Львів, Україна. E-mail: zhanna.d.parashchyn@Ipnu.ua, ORCID 0000-0002-4922-2371.

Лобур І. П. - асистент кафедри технології біологічно активних сполук, фрармації та біотехнології, Національний університет «Львівська політехніка», Львів, Україна. E-mail: ivanna.p.lobur@lpnu.ua, ORCID 0000-0003-0454-928X.

Фітьо І. В. - аспірант кафедри технології біологічно активних сполук, фармації та біотехнології Національного університету «Львівська політехніка», Львів, Україна. E-mail: irynadyakon@ukr.net, ORCID 0000-0003-3256-1374

\section{Information about the authors}

Stadnytska N. Ye. - PhD (Chemistry), Associate Professor of the Department of Technology of Biologically Active Substances, Pharmacy and Biotechnology, Lviv Polytechnic National University, Lviv, Ukraine. E-mail: nataliia.y.stadnytska@ Ipnu.ua, ORCID 0000-0001-6261-0275.

Parashchyn Zh. D. - PhD (Chemistry), Associate Professor of the Department of Technology of Biologically Active Substances, Pharmacy and Biotechnology, Lviv Polytechnic National University, Lviv, Ukraine. E-mail: zhanna.d.parashchyn@ Ipnu.ua, ORCID 0000-0002-4922-2371.

Lobur I. P. - assistant of the Department of Technology of Biologically Active Substances, Pharmacy and Biotechnology Lviv Polytechnic National University, Lviv, Ukraine. E-mail: ivanna.p.lobur@Ipnu.ua, ORCID 0000-0003-0454-928X.

Fito I. V. - PhD-student of the Department of Technology of Biologically Active Substances, Pharmacy and Biotechnology Lviv Polytechnic National University, Lviv, Ukraine. E-mail: irynadyakon@ukr.net, ORCID 0000-0003-3256-1374 